Niniejsza publikacja jest dostęna na licencji Creative Commons. Uznanie autorstwa-Użycie niekomercyjne-Bez utworów zależnych 3.0 Polska. Pewne prawa zastrzeżone na rzecz autora. Zezwala się na wykorzystanie publikacji zgodnie z licencja - pod warunkiem zachowania niniejszej informacji licencyjnej oraz wskazania autora jako właściciela praw do tekstu. Treść licencji jest dostępna na stronie: http://creativecommons.org/licenses/by-nc-nd/3.0/pl/

Lingwistyka Stosowana 24: 4/ 2017, 139-148

\author{
Aleksandra MONARCHA-MATLAK \\ Uniwersytet Szczeciński
}

\title{
Pojęcie komunikacji elektronicznej w doktrynie i aktach prawnych
}

\begin{abstract}
:
The concept of electronic communication in doctrine and legislation

Communication is the process of communication between people, that is, to transfer knowledge and information. Communication has always been foundation of social life, it connected people and their actions, it was promoting their development. Over time, when the form of direct contact became insufficient, other ways of transmitting information at a distance began to be sought. For this purpose, various forms of information transmission were used. Only electronic communication caused a kind of revolution in social communication, it allowed to overcome both the time and the space.
\end{abstract}

\section{Pojęcie komunikacji elektronicznej w doktrynie i aktach prawnych}

Komunikacja, to proces porozumiewania się ludzi, a więc przekazywania wiedzy i informacji. Pojęcie komunikacja pochodzi od łacińskiego słów communicare i communicatio tzn. połączyć, uczynić wspólnym, przekazywać informacje, porozumiewać się, czyli dwukierunkowy przepływ informacji oraz communio, które oznacza wspólność, poczucie łączności czyli wejście we wspólnotę. Z czasem komunikacja otrzymała inne znaczenie - transmisja i przekaz. W języku polskim stosowane są dwa pojęcia tj. „komunikacja” oznaczająca sposób porozumiewania się oraz transport. Chcąc uniknąć dwuznaczności zaleca się używanie w pierwszym przypadku terminu „komunikowanie się”. Komunikowanie, tym samym ogranicza się do zjawiska porozumiewania się ludzi. Komunikacja zawsze była dla ludzi fundamentem życia społecznego, łączyła ludzi i ich działania, zarówno na szczeblu lokalnym, ogólnopaństwowym, a także na całym świecie, sprzyjała ich rozwojowi. Z czasem forma bezpośredniego kontaktu stała się niewystarczająca, szukając zatem innych rozwiązań pozwalających na przekazywanie informacji na odległość, wykorzystywano rozmaite formy transmisji informacji.

Pierwszą z najstarszych form ludzkiej komunikacji była wieść, pogłoska, polegająca na przekazywaniu informacji za pośrednictwem innych osób. Chociaż taka forma komunikacji pozwalała na przekazanie informacji na odległość szerszemu gronu odbiorców, niemniej ze względu na wielość pośredników i zawodność ludzkiej pamięci, nie mogła stanowić gwarancji rzetelnego przekazania treści. Szukano wobec tego innych rozwiązań transmisji informacji (T. Goban-Klas/ P. Sienkiewicz 1999: 9 i nast.). 
Okazało się również, że nie tylko ważny jest sam przekaz informacji, ale także jej gromadzenie, stąd początkowo dla jej przechowywania, zawierzono ludzkiej pamięci. $\mathrm{Z}$ upływem lat jednak wytworzono bardziej trwałe, techniczne formy utrwalania obrazów i dźwięków. Były to początkowo ikonograficzne zapisy, takie jak rysunki, z czasem pojawiły się ideograficzne, sylabiczne i alfabetyczne - w postaci pisma. Nośnikami informacji były wypalane tabliczki, kamienne inskrypcje, w końcu papirus, pergamin i papier. Informacje chociaż utrwalone na papierze, mogły być już przekazywane na odległość, niemniej potrzebny był do tego dłuższy okres czasu i odpowiedni środek transportu, to wszystko w znacznym stopniu utrudniało prawidłowy przekaz (T. Goban-Klas/ P. Sienkiewicz 1999: 10). Dopiero komunikacja elektroniczna spowodowała swojego rodzaju rewolucję w komunikacji społecznej, pozwoliła na pokonanie zarówno czasu, jaki przestrzeni.

W najszerszym ujęciu komunikowanie jest zjawiskiem powszechnym i polega na wzajemnym kontakcie z otoczeniem. Komunikacja to termin oznaczający: 1 . transport - jako przenoszenie czegoś między nadawcą a i odbiorcą, na bliższą lub dalszą odległość; 2 . wymianę - jako wzajemne oddziaływanie na siebie stron w schemacie akcja - reakcja; 3. łączność - jako przekazywanie informacji na odległość z użyciem wybranego medium (telekomunikacja) (J. Janowski 2009: 36 i nast.). Telekomunikacja to dziedzina nauki i techniki obejmująca zagadnienia przekazywania na odległość wiadomości w postaci obrazów, dźwięków, znaków pisma, przy użyciu sygnałów czyli fal elektromagnetycznych lub impulsów elektrycznych (J. Janowski 2009: 36).

Dla właściwego zrozumienia natury komunikacji, należy podkreślić, że sama komunikacja międzyludzka jest procesem wymiany informacji. Komunikowanie się oznacza przede wszystkim, przekazywanie informacji, zawiadamianie o czymś, a samo komunikowanie się znaczy tyle co utrzymywanie z kimś kontaktu, porozumiewanie się, udzielanie się otoczeniu.

Chcąc uzyskać rzeczywisty dostęp do informacji, trzeba mieć realną możliwość inicjowania procesów komunikowania, którą to możliwość dają bez wątpienia „nowe media", stanowiące przy tym siłę napędową rozwoju nowego społeczeństwa, tzw. społeczeństwa informacyjnego.

Komunikacja elektroniczna obejmuje trzy odrębne dotychczas sektory: telekomunikację, technologie informacyjne i media elektroniczne (A. Monarcha-Matlak 2008: 59 i nast.). W wyniku konwergencji w jeden sektor komunikacji elektronicznej, zaistniała konieczność objęcia jednolitą regulacją prawną - sieci komunikacyjnych, elektronicznych usług komunikacyjnych i urządzeń towarzyszących (D. Adamski/ E. Galewska 2003: 147 i nast.).

Komunikacja obejmuje przede wszystkim infrastrukturę komunikacyjną i związane z nią usługi świadczone za pośrednictwem sieci telefonii stacjonarnej i komórkowej, sieci satelitarnych, radiowych i telewizyjnych sieci nadawczych, sieci telewizji kablowej, sieci teleinformatycznych. Obejmuje również urządzenia towarzyszące, które związane są z elektroniczną siecią komunikacyjną oraz usługami komunikacji elektronicznej. Regulacje dotyczące komunikacji elektronicznej powinny charakteryzować się neutralnością technologiczną, oznacza to, że żadna z technologii nie może być faworyzowana lub dyskryminowana. 
Komunikacja jest czynnością udzielania informacji czyli informowania i przekazywania wiadomości (zawiadamiania) (J. Mikułowski 1988: 11). Najszerzej rzecz ujmując, komunikacją będzie przekaz bez względu na to, co jest jego przedmiotem.. Przepływom materii i energii, towarzyszy przepływ informacji, która jest symboliczna. Materialny jest zawsze nośnik informacji, który może stanowić główny lub dodatkowy przedmiot przekazu. Komunikacja nie należy więc do istoty informacji, ale jest jej nieodłącznym atrybutem (J. Janowski 2009: 149 i nast.). Informacja zanim stanie się przedmiotem komunikacji, jest pozyskiwana z pierwotnych, wtórnych lub pochodnych jej źródeł. Proces powstawania, przekształcania, nadawania, transmisji oraz odbioru informacji obejmuje: źródło informacji, odbiorcę informacji, sygnał informujący, kodowanie informacji, kanał informacyjny. Są to elementy dynamiczne (zmienne) i konkretne (indywidualne) każdego komunikowania się (J. Janowski 2009: $150)$.

Komunikacja jest jednostronnym przekazem lub wzajemną wymianą informacji jako wiadomości, zawartych w komunikatach, obejmującą: 1 . Intencje nadawców (aspekt semantyczny) - zamierzone przez autora znaczenie komunikatu, 2. Reakcje odbiorców (aspekt pragmatyczny) - zmiany w środowisku spowodowane wystosowaniem komunikatu (J. Janowski 2009: 151). Komunikacja, nie tylko przenosi w czasie i przestrzeni jakąś treść (znaczenie) i jej nośnik jako sygnał (znak), ale zarazem przeobraża odbiorcę, a w dalszej kolejności także samego nadawcę. Dla potrzeb zakomunikowania informacja jest formułowana i utrwalana w różnych postaciach: teorii, koncepcji, poglądów, opinii, doktryn, wykresów, tabel, dźwięków, filmów, wiadomości. Składnikami komunikowania są: wiadomości - treści sformułowane, uświadomione; język-pośrednik przekazu znaczeń; nośnik - tworzywo służące do utrwalania; narzędzia - instrumenty zapisu i odczytu; operatorzy - instytucje zapewniające poprawne funkcjonowanie narzędzi.

Komunikacja cechuje się komunikatywnością, wynika to z celu jej nawiązywania i prowadzenia. Komunikacja, będąca transferem treści informacyjnej, ma charakter: zindywidualizowany (skierowany do konkretnego odbiorcy), grupowy (skierowany do określonej kategorii odbiorców), masowy (otwarty na każdego zainteresowanego), jednostronny (polega na publikacji), wzajemny (polega na interakcji), bezpośredni (w ramach osobistych kontaktów), pośredni (za pomocą nośników przekazu w czasie i przestrzeni) (J. Janowski 2009: 152).

Komunikacja zachodzi, gdy z daną czynnością wiąże się określony sens tzn. zostanie wykonana świadomie oraz czynność ta zostanie zauważona przez druga osobę, zostanie zmysłowo wychwycona. W ten sposób nadawca przekazuje odbiorcy w drodze swojego zachowania, określony komunikat (J. Janowski 2009: 155 i nast.). Jak wskazuje J. Janowski najprostszy schemat komunikacji międzyludzkiej obejmuje:

- nadawcę, czyli osobę inicjującą działanie. Osobę wykazującą się aktywnością fizyczną i psychiczną, dzięki której powstaje przekaz;

- przekaz - zakodowany sens za pomocą znaków utrwalonych na nośniku lub przenoszonych za pomocą nośnika;

- odbiorcę - osobę, będąca w stanie odczytać znaczenie poszczególnych znaków (J. Janowski 2009: 155). 
Komunikacja dokonuje się w ramach określonego systemu komunikacyjnego, co pociąga za sobą pewne koszty, takie jak: zdobycie informacji, jej zmagazynowanie, przetworzenie, przekazanie. Kosztem w takiej sytuacji jest także zużycie energii, eksploatacja odpowiednich urządzeń, wykorzystanie dostępnych materiałów, zaangażowanie ludzi, obsługa administracyjna, wysiłek intelektualny itd. Komunikacja wobec tego to nie stan czy sytuacja, ale ludzka aktywność. Komunikowanie jest czynnością celową i zamierzoną. Komunikując się chcemy coś osiągnąć, a tym samym dążymy do wywołania następujących reakcji: skupienia uwagi, bez której nie ma kontaktu. Dekodowania przekazu, bez którego nie ma odbioru oraz dalsze reakcje będące następstwem komunikowania, ze skutkiem jaki wywiera ono na psychikę i styl życia odbiorcy.

Chociaż współczesna komunikacja jest multimedialna, mobilna, globalna, interaktywna, anonimowa, to jednak wciąż jest interpersonalna. Utrata tego przymiotu spowoduje zanik komunikacji na rzecz sterowania i odbioru bodźców (J. Janowski 2009: 158).

\section{Komunikacja elektroniczna w obrocie prawnym}

Czynności konieczne do powstania przekazu, czyli wprowadzenia wiadomości do komunikatu, jest kodowaniem i znakowaniem. Natomiast czynności związane z odczytywaniem znaczenia i sensu przekazu, czyli wydobyciem wiadomości z komunikatu, jest dekodowaniem i interpretowaniem znaczenia. Im bardziej zaawansowany jest rozwój technologii informacyjno-komunikacyjnych, tym bardziej złożony jest proces kodowania i dekodowania w ramach komunikacji.

Szczególnym rodzajem komunikacji jest komunikacja elektroniczna, mierzona takimi parametrami jak: szybkość przekazu, jednoczesność (równoczesność) przekazu, pojemność przekazu, zintegrowanie przekazu, konwergencja czyli wielopłaszczyznowość oddziaływania na różne receptory zmysłowe. Zazwyczaj komunikowana wiadomość jest konstruowana przez nadawcę i rekonstruowana przez odbiorcę, natomiast komunikacja $\mathrm{w}$ ramach technologii informacyjno-komunikacyjnych, jest rezultatem złożonych i wielokrotnych operacji techniczno-fizycznych i formalno-logicznych. Przekazywana informacja $\mathrm{w}$ warstwie fizycznej - to bodziec, impuls, sygnał. W warstwie formalnej - to bit, znak, symbol; w warstwie semantycznej - to wiedza, świadomość, przekazywanie treści informacji do odbiorcy w formie zrozumiałej wiadomości. W warstwie pragmatycznej, w której informacja może być praktycznie przyjmowana i przetwarzana przez człowieka lub urządzenie - to dokument, dowód, oświadczenie (J. Janowski 2009: 153, G. Wierczyński/ W.R. Wiewiórowski 2012: $35)$.

Na tle powyższych rozważań, dodać należy, że z komunikacją mamy do czynienia dopiero wtedy, gdy treść zawarta w komunikacie zostanie odczytana. Wskazuje to, że komunikowanie elektroniczne jest aktywnością co najmniej dwóch stron, to jest: nadawcy oddziałującego na odbiorcę oraz odbiorcy oddziaływującego na nadawcę. Tam gdzie nie zachodzi odczyt intencji, czyli nie dokonano interpretacji znaczenia znaków zawartych w przesłanych sygnałach, tam ma miejsce sterowanie. Sygnał, który pełni rolę czynnika sterującego, nie musi być zauważony, rozumiany ani znany. Dlatego 
wyraźnie podkreśla się, że komunikacja nie zachodzi pomiędzy urządzeniami, ale ich użytkownikami (J. Janowski 2009: 153). Systemy informatyczne nie dokonują operacji określanych jako faza percepcyjna, taki poziom być może osiągną w przyszłości, gdy odpowiednio rozwiną się możliwości zastosowania sztucznej inteligencji w procesach interpretacyjnych prawa (G. Wierczyński/ W.R. Wiewiórowski 2012: 42-43) ${ }^{1}$.

Komunikacja elektroniczna, to przede wszystkim komunikacja za pośrednictwem komputerów. Elektroniczne postacie przekazu informacji przewyższają dotychczasowe sposoby komunikowanie się w obrocie prawnym. Komputerowy przekaz danych i informacji następuje szybciej, z wykorzystaniem różnorodnych narzędzi komunikacyjnych, w każdym czasie i z każdego miejsca. Przekaz ten odbywa się z możliwością selekcji zawartości komunikatów oraz doboru ich adresatów, z automatycznym generowaniem zawartości, swobodnym tłumaczeniem zawartości, z przesyłaniem dowolnej ilości materiałów.

Wyróżnia się różne typy komunikowania się elektronicznie np. za pomocą mowy (rozmowa telefoniczna, video konferencja), za pomocą tekstu (SMS. Email) za pomocą obrazów i symboli (przez klikniecie myszką) za pomocą automatycznej wymiany danych. Warunkiem obrotu prawnego jest rzeczywista komunikacja jako porozumiewanie się polegające na przekazywaniu i odbieraniu danych i informacji w formie dokumentów. Prawidłowa kwalifikacja przebiegu elektronicznej komunikacji wymaga odróżnienia od siebie niektórych pojęć. Po pierwsze ,,porozumiewanie się na odległość”, może mieć postać elektroniczną lub nieelektroniczną. Po drugie, „komunikacja elektroniczna" która następuje na odległość lub w tym samym miejscu (J. Janowski 2008: 109 i nast.).

Informacje mogą być odbierane bezpośrednio i na bieżąco lub na informatycznych nośnikach danych, dotyczy to także informacji wyrażonych w postaci oświadczeń woli i wiedzy. Komunikacja elektroniczna to: komunikacja internetowa - powszechna, łatwo dostępna, wykorzystująca technologie informacyjno - komunikacyjne do porozumiewania się na odległość oraz komunikacja poza internetowa, obejmująca inne elektroniczne sposoby porozumiewania się na odległość.

Intensywne wdrażanie nowych technologii informatycznych jako narzędzi komunikacji elektronicznej będzie pociągało za sobą zmiany w strukturach państwa i sposobach jego funkcjonowania. Jak na razie te zmiany są niewystarczające, co łatwo sprawdzić na przykładzie informatyzacji administracji publicznej. Nie były to zmiany rewolucyjne, ważniejsze zmiany organizacyjne dokonywały się bardziej ze względów politycznych, niż ze względu na wykorzystanie nowych technologii informacyjnokomunikacyjnych. Drugi front wpływu na rozwój komunikacji elektronicznej, to biznes technologii informatycznych, a więc dostawcy produktów tej branży. Obywatele coraz częściej kontaktują się z różnymi podmiotami publicznymi z wykorzystaniem IT (technologii informacyjnych), dlatego też dostawcom zależy na tym, aby komunikacja odbywała się wyłącznie z wykorzystaniem ich produktów, tym bardziej, że komunikacja elektroniczna coraz bardziej przekracza granice państwowe. Pomiędzy

\footnotetext{
${ }^{1}$ Autorzy nawiązują do procesu wykładni prawa M. Zielińskiego, zgodnie z którym, jest to cykl kolejnych operacji, podzielonych na trzy zasadnicze fazy: porządkującą, rekonstrukcyjną i percepcyjną (M. Zieliński 2010: 314 i nast.).
} 
tymi działaniami polityków i biznesu, znajdują się struktury organizacyjne państwa, że swoimi autonomicznymi systemami informatycznymi, ze swoją informatyzacją, z oczekującym na upowszechnienie podpisem elektronicznym, z dążeniami do informatyzacji urzędów, wymiaru sprawiedliwości, z dążeniami do zwiększenia liczby elektronicznych usług publicznych.

\section{Prawo komunikacji elektronicznej}

Prawo komunikacji elektronicznej jest stosunkowo młodą dziedziną prawa. Ma charakter kompleksowy i interdyscyplinarny. Obejmuje wybrane obszary prawa publicznego i prawa prywatnego, łącznikiem jest tutaj mniejszy lub większy udział komunikacji elektronicznej w powstawaniu, zmianie i ustawaniu stosunków prawnych należących do danej gałęzi prawa. Prawo to przejmuje aparaturę pojęciową oraz podstawowe rozwiązania, a najważniejszą jego cechą jest transgraniczność i dynamika rozwoju związana z postępem technologicznym. Prawo komunikacji elektronicznej powoduje, że powstaje nowa jakość działania, nowy sposób pracy i nowe zmiany organizacyjne. Jak słusznie zauważa G. Szpor, do języka prawnego wprowadzane są coraz częściej terminy i pojęcia informatyczne. W ramach procesów legislacyjnych podejmowane są fragmentaryczne próby porządkowania terminologii. Próby te są obarczone wadami i pokazują, że nie da się w tym trybie osiągnąc zgodnej z zasadami techniki prawodawczej spójności i przejrzystości regulacji (J. Gołaczyński 2010: i nast.). Zagadnienie polskiego prawa komunikacji elektronicznej powinno nabierać coraz pełniejszej treści w drodze kolejnych przybliżeń, poczynając od punktu wyjścia, którym jest pojęcie komunikacji elektronicznej, a kończąc na różnych zagadnieniach prawnych, stanowiących szczegółową materię ustrojową. Prawo to objęło jednym „węzłem prawnym” telekomunikację, media elektroniczne i technologie informacyjne. To właśnie przenikanie czy przechodzenie w komunikacji elektronicznej pociąga za sobą konieczność uelastycznienia, także obecnego porządku prawnego. $\mathrm{Na}$ przykład silnie zaznaczone $\mathrm{w}$ administracji przydziały zadań, kompetencji, poparte często uregulowaniami konstytucyjnymi, w administracji elektronicznej nie znajdują już tak pewnego, prawnego uzasadnienia. Sensowne z punktu widzenia prawa konstytucyjnego i administracyjnego, będzie rozbudowanie kontaktów na linii obywatel - urząd elektroniczny, gdzie zadania urzędów będą dopasowane do indywidualnych potrzeb obywateli. Spowoduje to trwałe przesuniecie większości kompetencji na szczebel samorządowy. Już teraz daje się zauważyć zwiększone skupienie zadań na szczeblu gminnym wraz ze zwiększaniem się możliwości technologicznych, z wyposażeniem w technologie informacyjno-komunikacyjne. Taki szkic obrazu prawnej konstrukcji administracji elektronicznej pokazuje, że w jej ramach sprawy będą przesuwane i załatwiane wyłącznie w układzie poziomym, miedzy wydziałami. Wybór właściwych środków komunikacji elektronicznej powinien należeć do obywateli. Odpowiednie załatwianie spraw zgodnie z dobrą praktyką administracyjną będzie możliwe w ramach administracji elektronicznej, dzięki przejęciu części „oprogramowania" prawnego instytucji, przejęcia kompetencji, ustalonych faz postępowania i elementów decyzji, czyli „,prawnego dopasowania”. Infrastruktura techniczna administracji elektronicznej przekracza zakresy „pojedynczych” rodzajów administracji tzn. 
administracji rządowej i samorządowej. Możliwości administracji elektronicznej są uzależnione od przesłanek technicznych, które również będą stanowiły o nowej jakości administracji. Postępowanie w ramach administracji elektronicznej pozwala na wyraźne umiejscowienie odpowiedzialności decyzyjnej i na przejrzystość odpowiedzialności.

Na poziomie europejskim również jesteśmy świadkami porządkowania prawa komunikacji elektronicznej. Coraz wyraźniejsze są przepisy dotyczące harmonizacji, wspierania, rozwoju i rozbudowy paneuropejskich usług elektronicznych. To także europejska ochrona danych osobowych, to unijne postępowanie administracyjne oraz unijne przepisy dotyczące identyfikacji elektronicznej i usług zaufania publicznego. Przykładów można by podawać znacznie więcej, to tylko wybrane, najbardziej transparentne. Problematyczne jest „upchnięcie” wszystkiego w jeden tytuł ,europejska komunikacja elektroniczna”, ale kierunek został już obrany, to przede wszystkim rozbudowa infrastruktury technicznej (A. Monarcha-Matlak 2008: 318). Jesteśmy świadkami inwazji technologii informacyjno-komunikacyjnych w wewnętrzne obszary prawa, które są zgrabnie etykietowane np. e-administracja, e-urząd, e-zdrowie, e-podatki, e-zamówienia publiczne. Technologie informacyjne stały się częścią składową modernizacji władzy publicznej. Początkowo były tylko środkiem do odciążenia, a teraz przyczyniają się do zmiany administrowania, a to już musi być ujęte w nowe ramy prawne. Powiązanie komunikacji elektronicznej z naukami prawnymi jest bardzo trudne. $Z$ jednej strony, nowe struktury logiki matematycznej, reguły związane $\mathrm{z}$ informatyka, a z drugiej - rzeczywiste reguły prawne.

We wrześniu 2016 r. Komisja Europejska zaproponowała przegląd przepisów UE dotyczących komunikacji elektronicznej oraz wskazała nowe inicjatywy dotyczące zaspokojenia rosnących potrzeb Europejczyków odnośnie dostępu do Internetu. Komisja przedstawiła trzy cele strategiczne, które należy osiągnąć do 2025 r., są to: 1 . dostęp do łączności o szczególnie dużej przepustowości tzw. łączności gigabitowej, 2. dostęp do Internetu wszystkich gospodarstw domowych w Europie, 3. niezakłócony zasięg sieci komórkowej piątej generacji $(5 \mathrm{G})$. W ramach nowych ram prawnych dla komunikacji elektronicznej, Komisja Europejska przewiduje następujące cele: większą konkurencyjność i przewidywalność inwestycji, lepsze wykorzystanie częstotliwości radiowych, lepszą ochrona konsumentów, środowisko Internetu bezpieczniejsze dla użytkowników oraz bardziej sprawiedliwe reguły gry dla wszystkich podmiotów. W celu osiągnięcia wszystkich wyżej wymienionych celów przedstawiono projekt dyrektywy ustanawiającej „Europejski Kodeks Komunikacji Elektronicznej”. W kodeksie Komisja Europejska zaproponowała szereg zmian prawnych dotyczących m.in. dodanie promowania dostępu do bardzo szybkich sieci jako nowego celu dla regulatorów, przyznanie praw do wykorzystywania częstotliwości na minimum 25 lat, określenie przypadków, kiedy można odmówić dostępu do okablowania wewnątrz i poza budynkiem, maksymalną harmonizację przepisów dotyczących użytkowników końcowych.

Komunikacja elektroniczna i związane z nią technologie informacyjno-komunikacyjne (ICT) są źródłem trwałego wzrostu gospodarczego, przyczyniając się do wzrostu produktywności o 50\% we wszystkich sektorach gospodarki, w których są 
stosowane. Nawet jeśli ich zastosowanie powoduje zmniejszenie zatrudnienia na konkretnych stanowiskach, to utratę każdych 2 miejsc kompensuje 5 powstających nowych miejsc pracy. ${ }^{2}$ Gospodarka cyfrowa i jej produkty mają coraz wyższy udział w PKB, a usługi komunikacji elektronicznej są kluczowe dla wzrostu produktywności we wszystkich sektorach gospodarki - od ochrony zdrowia po energetykę i usługi publiczne. Kluczowym czynnikiem rozwoju jest także możliwość inwestowania w sieci łączności bezprzewodowej (czwarta generacja technologii łączności ruchomej zapewniająca szybki mobilny dostęp do Internetu i następne) oraz szybkie sieci stacjonarne. Dla zapewnienia wysokiej rentowności sieci komunikacji elektronicznej trzeba osiągnąć dostatecznie dużą skalę działania. Tymczasem rynek komunikacji elektronicznej krajów UE jest bardzo rozdrobniony, działa na nim ponad 1000 operatorów stacjonarnych i kilkuset operatorów sieci mobilnych. Silni operatorzy w Stanach Zjednoczonych, Japonii i Korei Południowej poczynili ogromne inwestycje w infrastrukturę szybkich szerokopasmowych łączy internetowych stacjonarnych i bezprzewodowych. Dla Unii Europejskiej kwestią niezwykle ważną jest utrzymanie konkurencyjności globalnej w dziedzinie komunikacji elektronicznej. Wzrost dostępności szybkich sieci oraz obniżenie kosztów ich budowy, przyniesie ogromne możliwości tworzenia nowych usług, które będą wykorzystywane w dziedzinach, w których spodziewany jest szybki rozwój, takich jak „Internet rzeczy” (IoT - Internet of Things) oraz komunikacja międzymaszynowa (M2M - Machine-to-Machine).

Szczególną rolę w ramach komunikacji elektronicznej pełnią również usługi zaufania publicznego, stanowiące centralny obszar rozwojowy.

\section{Uslugi zaufania oraz identyfikacja elektroniczna}

Wejście w życie rozporządzenia Parlamentu Europejskiego i Rady UE nr 910/ 2014 z dnia 23 lipca 2014 r. w sprawie identyfikacji elektronicznej i usług zaufania w odniesieniu do transakcji elektronicznych na rynku wewnętrznym oraz uchylające dyrektywę 1999/93/WE (e-IDAS) spowodowało pojawienie się nowych, dotychczas nie znanych prawu terminów, takich jak: identyfikacja elektroniczna, uwierzytelnianie elektroniczne, systemy i środki identyfikacji elektronicznej, usługi zaufania oraz środki do ich realizacji. Celem rozporządzenia jest ujednolicenie i opracowanie wspólnych procedur identyfikacji elektronicznej oraz usług zaufania służących ułatwieniu i zabezpieczeniu transakcji elektronicznych na rynku wewnętrznym. Celem

\footnotetext{
${ }^{2}$ Opinia Europejskiego Komitetu Ekonomiczno-społecznego w sprawie nowych środków na jednolitym rynku UE w dziedzinie telekomunikacji, na które składają się następujące dwa dokumenty: wniosek dotyczący rozporządzenia Parlamentu Europejskiego i Rady ustanawiającego środki dotyczące europejskiego jednolitego rynku łączności elektronicznej mające na celu zapewnienie łączności na całym kontynencie, zmieniającego dyrektywy 2002/20/WE i 2002/22/WE oraz rozporządzenia (WE) NR 1211/2009 (UE) NR 531/2012 COM(2013) 627FINAL - 2013/0309 (COD) oraz komunikat Komisji do Parlamentu Europejskiego, Rady, Europejskiego Komitetu Ekonomiczno-Społecznego i Komitetu Reginów w sprawie jednolitego rynku telekomunikacyjnego COM (2013) 634 FINAL z dnia 11 czerwca 2014 r. (Dz. Urz. UE. C Nr 177: 64).
} 
rozporządzenia jest również zwiększenie zaufania do usług online, pozwoli to na podniesienie efektywności usług prywatnych i publicznych online, e-biznesu, e-handlu w Unii Europejskiej. Budowanie zaufania do środowiska online jest kluczowe dla rozwoju gospodarczego i społecznego. Osiągnięcie zamierzonego stanu, jest możliwe przez zniesienie barier w transgranicznym stosowaniu środków identyfikacji elektronicznej używanych w państwach członkowskich UE w celu uwierzytelnienia. Rozporządzenie jest kompleksowym aktem prawnym umożliwiającym rozwój usług zaufania publicznego i identyfikacji elektronicznej na poziomie europejskim. Rozporządzenie implikuje nowy porządek prawny w obszarze usług zaufania publicznego, co spowodowało konieczność dostosowania prawa krajowego do nowych uwarunkowań. W polskim prawie uregulowana była dotychczas instytucja podpisu elektronicznego oraz znakowanie czasem, w związku z tym, że polskie rozwiązania nie przystawały do rozporządzenia eIDAS, niezbędne było uchylenie ustawy o podpisie elektronicznym oraz powstrzymanie się co do zasady od regulowania tej materii przepisami prawa krajowego. Rozporządzenie eIDAS poszerzyło gamę dostępnych usług zaufania takich jak: pieczęć elektroniczna, elektroniczny znacznik czasu, usługa rejestrowanego doręczenia elektronicznego, uwierzytelnianie witryn internetowych. Polska ustawa z dnia 5 września 2016 r. o usługach zaufania oraz identyfikacji elektronicznej (Dz.U z 2016 r. poz. 1579) dostosowuje terminologię oraz wprowadza niezbędne odwołania do rozporządzenia eIDAS. Zmianie uległa cała siatka pojęciowa funkcjonująca dotychczas w wielu aktach prawnych w Polsce, dotyczy to w szczególności zastąpienia bezpiecznego podpisu elektronicznego weryfikowanego ważnym certyfikatem kwalifikowanym przez kwalifikowany podpis elektroniczny oraz znakowania czasem przez kwalifikowany znacznik czasu. Terminologia rozporządzenia eIDAS została ujednolicona na poziomie europejskim i z tego względu cały krajowy porządek prawny w zakresie komunikacji elektronicznej musi być do niej dostosowany.

Podsumowując należy jeszcze tylko dodać, że komunikacja elektroniczna jest obecnie jednym z narzędzi nacisku do zmiany roli rządu, struktur państwowych, administracji. Komunikacja elektroniczna jest jednym z wielu czynników wpływających na nowy sposób myślenia o ,przestrzeni władzy”. Historycznie ukształtowany dystans między znajomością prawa, polityki i praktyk administracyjnych przez urzędników i obywateli znacznie się zmniejszył. Informacje mogą być udostępniane wszystkim, w dowolnym miejscu i czasie. Komunikacja elektroniczna nie zatrzymuje się na granicach państwa. Natomiast państwo przestaje być obiektem lojalności, staje czymś niewiele większym niż, geograficznym i językowym miejscem, powstałym ze specyficznych traktatów oraz miejscem dóbr kultury.

\section{Bibliografia}

Goban-Klas, T./ P. Sienkiewicz (1999), Społeczeństwo informacyjne: Szanse, zagrożenia, wyzwania (Społeczeństwo Globalnej Informacji). Kraków, 9-10.

Janowski, J. (2009), Administracja elektroniczna: ksztattowanie się informatycznego prawa administracyjnego i elektronicznego postępowania administracyjnego $w$ Polsce. Warszawa, 36-40. 
Monarcha-Matlak, A. (2008) Obowiazki administracji w komunikacji elektronicznej (Prawo jest na naszej stronie). Warszawa, 59-61 .

Adamski, D./ E. Galewska (2003) Europejskie prawo komunikacji elektronicznej w prawie Unii Europejskiej, (w:) J. Gołaczyński (red.) Prawne i ekonomiczne aspekty komunikacji elektronicznej. Warszawa, 147-150.

Mikułowski-Pomorski, J. (1988) Informacja i komunikacja. Pojęcia $i$ wzajemne relacje. Wrocław, 11-12.

Janowski, J. (2009) Technologia informacyjna dla prawników i administratywistów. Warszawa, 149-155.

Wierczyński, G./ W.R. Wiewiórowski, (2012) Informatyka prawnicza. Nowoczesne technologie informacyjne $w$ pracy prawników $i$ administracji publicznej (Seria Akademicka). Warszawa.

Janowski, J. (2008) Elektroniczny obrót prawny (Seria Akademicka Prawo). Warszawa, 109-110.

Gołaczyński, J. (2010) (red.) Informatyzacja postępowania sadowego i administracji publicznej (Biblioteka Sądowa). Warszawa. 